МЕХАНІЗМИ ВЗАЄМОДІЇ ДЕРЖАВИ ТА БІЗНЕСУ У СФЕРІ ВИЩОЇ ОСВІТИ

\title{
THE MECHANISM OF INTERACTION OF THE STATE AND BUSINESS IN THE FIELD OF HIGHER EDUCATION
}

у статті розкриваються проблеми та перспективи взаємодії державних і приват них структур в освіті, серед яких виділені основні проблеми, що перешкоджають ефективному розвитку приватно-державного партнерства в освітній сорері. Ефективність розвитку цієї форми парт нерського співробітничтва багато в чому розширює можливості навчальних закладів у підготовці фрахівців більш високого рівня а для бізнес-структур відкриває можливості кадрового оновлення виробництва від повідно до потреб інноваційного розвитку економіки, у зв'язку з чим у статті показано що розвиток приватно-державного парт нерства має в Україні великі перспективи. Наголошено, що сутність взаємодії держави та бізнесу в рамках проєктів полягає у формуванні партнерських відносин, які явля ють собою не просте складання ресурсів, а необхідність узгодження інтересів. Визна чено, що ефективність діяльності держави в реалізації проєктів в основному залежить, з одного боку, від потреби в ресурсах бізнесу, а, з іншого боку, усвідомленості в необхід ності залучення недержавних структур до розвитку освітніх установ. Отже, в основ взаємодії держави і бізнесу лежить усвідомлена необхідність як з боку держави, так бізнесу у плідній співпраці в освітній сорері. Доведено, що основні напрямки стимулювання цього процесу повинні зосередитися на прямій державній участі в освітніх проєктах, що мають національний пріоритет у здійсненні державної підтримки інноваційно діяльності бізнес-структур через кредитування, пільгове оподаткування та інші преферениіі, що полегшують умови діяльност підприємств. Партнерство у сорері вищо освіти стимулює об'єднання держави, біз нес-спільноти та освітніх організацій для реалізації соціально орієнтованих проєктів та надання державних послуг.

Ключові слова. приватно-державне парт нерство, взаємодія держави і бізнесу, якість освіти, підприємницькі ризики, співпраця
The article reveals the problems and prospects of interaction between public and private structures in education, among which the main problems that hinder the effective development of public-private partnership in the educational sphere are highlighted. The effectiveness of the development of this form of partnership cooperation greatly expands the possibilities of educational institutions in training higher-level specialists, and for business structures opens up the possibility of personnel renewal of production in accordance with the needs of innovative economic development, in this connection, the article shows that the development of public-private partnership in Ukraine has great prospects. It is noted that the essence of interaction between the state and business in the framework of projects is the formation of partnerships, which are not a simple addition of resources, but the need to coordinate interests. It is determined that the effectiveness of the state in the implementation of projects mainly depends, on the one hand, on the need for business resources, and, on the other hand, on awareness of the need to involve non-state structures in the development of educational institutions. So, the interaction between the state and business is based on the conscious need for both the state and business to cooperate effectively in the educational sphere. It is proved that the main directions of stimulating this process should focus on direct state participation in educational projects that have a national priority in the implementation of state support for innovative activities of business structures through lending, preferential taxation and other preferences that facilitate the conditions of enterprises activities. Partnership in the field of higher education encourages the unification of the state, the business community and educational organizations for the implementation of socially oriented projects and the provision of public services.

Key words. public-private partnership, interaction between the state and business, the quality of education, entrepreneurial risks, cooperation.
Постановка проблеми в загальному вигляді. Важливість системи освіти для функціонування та розвитку суспільства будь-якої країни очевидна. Сьогодні заклади вищої освіти в Україні стикаються із значною кількістю проблем, зокрема зниження чисельності студентів та абітурієнтів, низький рівень фінансування вищої освіти, застарілість матеріального фонду, відірваність від наукових досліджень, повільні темпи інтеграції в європейський та світовий інтелектуальний простір тощо [1-5]).

Одним з можливих напрямів їхнього розв'язання, хоча й не єдиним, $€$ налагодження співпраці закладів вищої освіти (далі - 3ВО) 3 державним сектором та бізнес-структурами на взаємовигідних умовах. Така співпраця може бути корисною для трьох сторін. Проте сьогодні у такій співпраці є дуже багато проблем. Хоча очевидно, що такі сектори не лише залежать один від іншого, але й їхня взаємодія є важливою умовою нормалізації ситуації у національній економіці будь-якої країни. Тому потребує уточнення базис взаємодії вітчизняних 3ВО, держави та бізнес-структур, в основу якого доцільно покласти положення теорії взаємодії.

Аналіз останніх досліджень та публікацій. Теоретичні та практичні аспекти взаємодії державно-приватного партнерства (далі - ДПП) у галузі освіти в умовах глобальної інтеграції розглянуто в працях українських 
учених, зокрема І. Вахович, М. Згуровский, Л. Іщук, С. Кучеренко, В. Огнев'юк, С. Пиріг, І. Поправка, І. Семенець-Орлова, Ю. Схулухія, В. Усик, Н. Холявко, Т. Ящук та ін.

Виділення невирішених раніше частин загальної проблеми. Невирішеним залишається пошук ефективних механізмів співпраці бізнесу і влади щодо поліпшення якості освітніх послуг в Україні.

Метою статті $€$ дослідження механізмів взаємодії держави та бізнесу у сфері вищої освіти.

Виклад основного матеріалу. Зростаючий інтерес державних органів влади та реального сектора економіки до реалізації потреб у кваліфікованих кадрах призводить до того, що одним з пріоритетних напрямків розвитку вищої освіти є формування ефективних механізмів партнерства між бізнес-спільнотою, державою в частині надання економічної підтримки освітнім організаціям, управління змістом освітнього процесу і науково-дослідною діяльністю.

Реалізація даного підходу базується на комплексі перетворень, одним з яких є "структурна диверсифікація економіки на основі інноваційного технологічного розвитку, в тому числі формування національної інноваційної системи, включаючи такі елементи, як інтегрована з вищою освітою система наукових досліджень і розробок, яка гнучко реагує на запити з боку економіки" [1]. Успішна реалізація даної концепції вимагає формування нового рівня взаємовідносин між ЗВО та бізнесом, що в сучасних умовах стає можливо на основі розвитку партнерських відносин держави і бізнесу в сфері освіти.

ДПП - визначається як форма співпраці між органами державної влади та бізнесом, основною метою якої $€$ забезпечити фінансування, реконструкцію, управління та утримання об'єкта інфраструктури або надання послуги [8; 12].

Можна відзначити наступні характеристики ДПП:

- довгостроковий характер відносин;

- об'єднання ресурсів під досягнення конкретного результату;

- розподіл відповідальності та ризиків між приватним і державним партнером.

Варто наголосити, що сутність взаємодії держави та бізнесу в рамках ДПП полягає у формуванні партнерських відносин, які являють собою не просте складання ресурсів, а необхідність узгодження інтересів. Це випливає 3 того, що кожна зі сторін партнерства має власні цілі, та прагне вирішувати свої конкретні завдання. У таких відносинах заці- кавлені усі сторони проєктів: для держави партнерство з бізнесом - це спосіб залучити приватний капітал до фінансування освітньої галузі, отже, з одного боку, мінімізація ризиків участі в інвестиційних проєктах; для підприємницьких структур - це шлях отримання від держави сприятливих умов господарювання, забезпечення гарантованого прибутку від участі у вигідних спільних проєктах, реалізація потреб у кадрових ресурсах; для ЗВО - оновлення матеріально-технічної бази, отримання прибутку від оренди приміщень, можливість працевлаштування випускників та ін. [11].

В цьому контексті слід зазначити, що ефективність діяльності держави в реалізації розглянутих питань в основному залежить, з одного боку, від потреби в ресурсах бізнесу, a, з іншого боку, усвідомленості в необхідності залучення недержавних структур до розвитку освітніх установ. Отже, в основі взаємодії держави і бізнесу лежить усвідомлена необхідність як з боку держави, так і бізнесу у плідній співпраці в освітній сфері (рис. 1).

Крім того, участь приватних компаній відкриває для них нові можливості розвитку інноваційного бізнесу, зокрема, отримання доступу до результатів наукових досліджень і розробок, доступу до інфраструктури, а також до високотехнологічного обладнання 3BO.

Окрім вище перелічених проєктних переваг, які отримують користувачі результатами проєкту ДПП, можна виділити також так звані регіональні переваги. Тобто можна розглядати користь для суспільства в двох площинах: проєктній та регіональній. У регіональній площині знаходяться, наприклад, такі переваги, як створення нових робочих місць, залучення інвестицій, підвищення привабливості регіону за рахунок надання якісних та сучасних освітніх послуг та ін. [13; 14].

До основних проблем реалізації державно-приватного партнерства у сфері освіти можна віднести наступні:

- недосконалість законодавчої бази, яка знаходить прояв у відсутності податкових стимулів для співпраці з освітніми закладами зі сторони бізнесу. Так, наприклад, витрати українських організацій на навчання персоналу становлять 0,7\% від прибутку, в той час як в західних країнах - 10-12\% [2]. Відсутня алгоритм спільного засновництва освітніх установ державними органами та приватними особами, не опрацьована нормативна база по регламентації і розвитку механізмів реалізації автономних установ, що гальмує розвиток практики його застосування; 


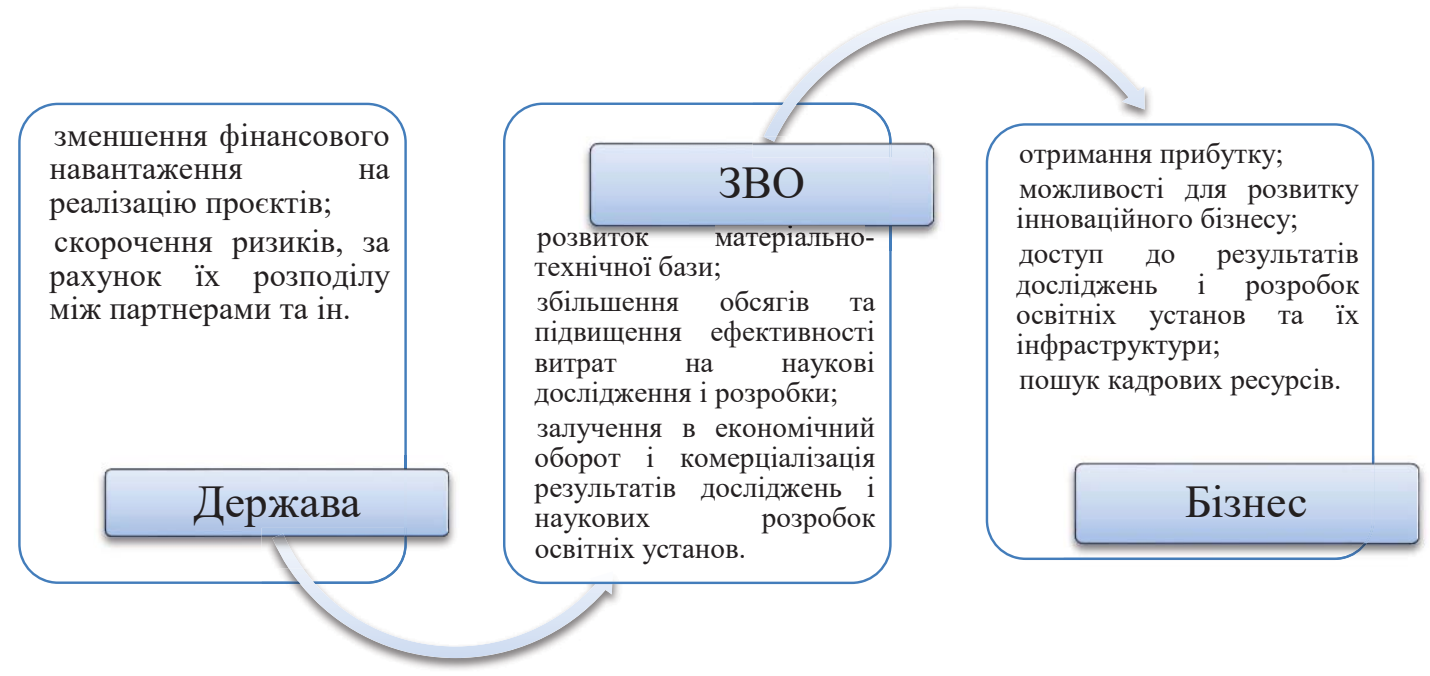

Рис. 1. Мотивація взаємодії учасників дПп у сфері освіти [4; 8; 10; 11].

- відсутність фінансової зацікавленості комерційних організацій, що пов'язано з неможливістю віднесення на собівартість продукції в повному обсязі витрат комерційних організацій з підготовки, перепідготовки та підвищення кваліфікації працівників, а також витрати на утримання освітніх центрів всередині підприємства;

- відсутність сталого бюджетного фінансування ЗВО породжує високі ризики при реалізації освітніх проєктів, що зменшує можливості обліку витрат за такими проєктами для бізнесструктур і знижує їх зацікавленість у вкладенні фінансових коштів у довгостроковій перспективі;

- низька кваліфікація фахівців у галузі створення та управління проєктами в рамках ДПП як в освітніх структурах, державному секторі, так і приватних підприємствах [5; 8; 9].

Разом з тим, основні проблеми розвитку ДПП у сфері освіти лежать у площині законодавчого забезпечення. За умови пошуку ефективних шляхів їх вирішення, може стати ефективним механізмом розвитку української освіти, що може стимулювати розвиток переваг як для державної системи освіти, так і для освітніх закладів, суть яких полягає в наступHомy:

- розвиток ринку та посилення добросовісної конкуренції на ринку освітніх послуг;

- створення нових організаційно-правових форм об'єднання освітніх установ з бізнесом;

- удосконалення нормативно-правової бази в умовах реформування освіти;

- відпрацювання механізмів фінансування розвитку ЗВО;

- впровадження механізмів взаємодії ЗВО та роботодавців;
- удосконалення освітніх стандартів з урахуванням реальних потреб ринку праці;

- створення навчально-виробничої інфраструктури на базі освітнього закладу для інноваційної діяльності компаній;

- залучення студентів та професорсько-викладацького складу до виконання науково дослідницьких робіт та спільних проєктів з участю бізнесу;

- розвиток ринку освітніх послуг та ін. [3; 14].

Таким чином, стимулювання активності участі бізнес-структур у розвитку освітніх установ має стати частиною державної економічної політики, оскільки від ефективності цього процесу залежить перехід економіки країни на інноваційний шлях розвитку. Основні напрямки стимулювання цього процесу повинні зосередитися на прямій державній участі в освітніх проєктах, що мають національний пріоритет у здійсненні державної підтримки інноваційної діяльності бізнес-структур через кредитування, пільгове оподаткування та інші преференції, що полегшують умови діяльності підприємств.

Отже, держава, як основний правовий регулятор системи вищої освіти, виступає в ролі зацікавленої сторони, приймаючи рішення, які враховують зовнішні впливи демографічних, економічних і політичних факторів. Формуються показники державного замовлення та приймального контролю, розвивається моніторинг ефективності ЗВО, науково-педагогічні працівники ґрунтуючись на отриманих рекомендаціях, розробляють стратегії та освітні програми. Через зворотний зв'язок з кафедрами керівництво закладу освіти звітує про свою діяльність [10]. 
Система ДПП також має зворотний зв'язок з бізнес-середовищем, в ході якої роботодавець має можливість коригувати завдання державного сектора. Випускник, як результат освітньої діяльності, $€$ наслідком взаємодії ЗВО і бізнес-спільноти через органи державної влади. При цьому інтереси партнерів спрямовані на зміцнення конкурентоспроможності шляхом досягнення ефективного розподілу ресурсів або на створення цільових показників, що забезпечують необхідні показники ефективності, шляхом постановки чітких цілей і завдань з формулюванням подальших дій по їх досягненню.

На думку І. Семенець-Орлової [14] в процесі реалізації проєктної діяльності повинна здійснюватися паралельна корекція плану, що дозволяє враховувати вимоги конкретних підприємств до компетенцій випускників. 3 метою забезпечення узгодженості при створенні таких проєктів можуть бути використані коефіцієнти значущості певних характеристик випускників, отримані від кожного із зацікавлених сторін. Одночасно необхідно вдосконалити організацію та проведення навчального процесу, практико-орієнтовану освітню програму, науково-дослідну роботу та ін.

Варто також наголосити, що існують дві основні форми взаємодії проектів тріади "держава-бізнес-освіта": інституційна та договірна. Інституційні проєкти у сфері вищої освіти спрямовані на створення нових спільних інноваційних структур і мають практику ефективного застосування за кордоном (США, Канада, Великобританія, Німеччина та ін.): ендаумент-фонди, дослідницькі центри, базові кафедри та ін. Проєкти контрактного партнерства зацікавлених сторін у сфері вищої освіти найбільш поширені в країнах з перехідною економікою, в тому числі і в Україні.

Отже, партнерство у сфері вищої освіти стимулює об'єднання держави, бізнес-спільноти та освітніх організацій для реалізації соціально орієнтованих проєктів та надання державних послуг.

Висновки. Різні форми взаємодії зацікавлених сторін у сфері вищої освіти роблять істотний вплив на характер, ефективність, сучасність відносин між державою і бізнес-спільнотою, забезпечуючи плідну співпрацю і знижуючи ймовірність виникнення різ- них конфліктних факторів та ризиків, а також удосконалюючи систему відтворення людського капіталу для забезпечення послідовності і збалансованості в розвитку ринків праці та освітніх послуг.

\section{ЛІТЕРАТУРА}

1. Вахович І. М., Іщук Л. І., Пиріг С. О. Стан і проблеми вищої освіти в Україні. Актуальні проблеми економіки. 2014. № 1 (151). С. 63-69.

2. Кучеренко С. Ю. Сучасний стан, тенденції та проблеми розвитку освіти в Україні. Економічний вісник Переяслав Хмельницького державного педагогічного університету імені Григорія Сковороди. 2018. № 36 (1). C. 51-58.

3. Огнев'юк В. Український університет у добу експонентного розвитку. Освітологічний дискурс. 2018. № 1-2. C. 1-25.

4. Усик В. І., Схулухія Ю. В. Корупція у вищій освіті як загроза академічній доброчесності. Економіка та держава. 2017. № 11. С. 65- 67.

5. Ящук Т. А. Аналіз сучасного стану фрінансового забезпечення вищої освіти в Україні. Молодий вчений. 2018. № 1. С. 1026-1030.

6. Курбатов С. Корпоративний університет як продукт співпраці бізнесового та освітнього середовища в сучасних умовах. Вища освіта України. 2014. № 3. С. 44-49.

7. Холявко Н. І. Сектор вищої освіти в системі інноваційного розвитку національної економіки. Економіка і управління. 2014. № 1. С. 33-37.

8. Поправка И. Сотрудничество бизнеса с вузами: возможности для обеих сторон. Управление персоналом. Украина. 2014. № 2. С. 28-29.

9. Etzkowitz H., Goktep-Hulten D. Maybe they can? University technology transfer offices as regional growth engines. Int. J. Technology Transfer and Commercialisation. 2019. Vol. 9. Nos. 1/2. P. 166-181.

10. Etzkowitz H., Webster A., Gebhardt C. The future of the university and the university of the future: evaluation of ivory tower to entrepreneurial paradigm. Research Policy. 2000. No. 29. P. 313-330.

11. Згуровский М. 3. Дослідницькі університети як центри інноваційного розвитку країни. Дзеркало тижня. 2011. № 2.

12. Porter M. E. Competitive advantage: creating and sustaining superior performance. New York: Free press. $658 \mathrm{p}$.

13. Niederkofler Dr. M. The Evolution of Strategic Alliances. Journal of Business Venturing. 1991. Vol. 6, issue 4. P. 237-257.

14. Semenets-Orlova I. Tendencies in reforming the educational system of modern Ukraine: national and regional aspects. Public management : collection. № 2 (12). February 2018. Kyiv, 2018. P. 171-179. 